\title{
Investigations of primary and secondary particulate matter of different wood combustion appliances with a high-resolution time-of-flight aerosol mass spectrometer
}

\author{
M. F. Heringa ${ }^{1}$, P. F. DeCarlo ${ }^{1, *}$, R. Chirico ${ }^{1, * *}$, T. Tritscher $^{1}$, J. Dommen ${ }^{1}$, E. Weingartner ${ }^{1}$, R. Richter ${ }^{1}$, G. Wehrle ${ }^{1}$, \\ A. S. H. Prévôt ${ }^{1}$, and U. Baltensperger ${ }^{1}$ \\ ${ }^{1}$ Laboratory of Atmospheric Chemistry, Paul Scherrer Institut, 5232 Villigen PSI, Switzerland \\ *now at: AAAS Science and Technology Policy Fellow hosted at the US EPA, Washington, DC, USA \\ ** now at: Italian National Agency for New Technologies, Energy and Sustainable Economic Development (ENEA), \\ UTAPRAD-DIM, Via E. Fermi 45, 00044 Frascati, Italy
}

Received: 18 February 2011 - Published in Atmos. Chem. Phys. Discuss.: 9 March 2011

Revised: 7 June 2011 - Accepted: 13 June 2011 - Published: 23 June 2011

\begin{abstract}
A series of photo-oxidation smog chamber experiments were performed to investigate the primary emissions and secondary aerosol formation from two different $\log$ wood burners and a residential pellet burner under different burning conditions: starting and flaming phase. Emissions were sampled from the chimney and injected into the smog chamber leading to primary organic aerosol (POA) concentrations comparable to ambient levels. The composition of the aerosol was measured by an Aerodyne high resolution time-of-flight aerosol mass spectrometer (HR-TOFAMS) and black carbon (BC) instrumentation. The primary emissions were then exposed to xenon light to initiate photo-chemistry and subsequent secondary organic aerosol (SOA) production. After correcting for wall losses, the average increase in organic matter $(\mathrm{OM})$ concentrations by SOA formation for the starting and flaming phase experiments with the two log wood burners was found to be a factor of $4.1 \pm 1.4$ after five hours of aging. No SOA formation was observed for the stable burning phase of the pellet burner. The startup emissions of the pellet burner showed an increase in OM concentration by a factor of 3.3. Including the measured SOA formation potential, average emission factors of $\mathrm{BC}+\mathrm{POA}+\mathrm{SOA}$, calculated from $\mathrm{CO}_{2}$ emission, were found to be in the range of 0.04 to $3.9 \mathrm{~g} / \mathrm{kg}$ wood for the stable burning pellet burner and an old log wood burner during startup respectively. SOA contributed significantly to the ion $\mathrm{C}_{2} \mathrm{H}_{4} \mathrm{O}_{2}^{+}$at mass to charge ratio $m / z 60$, a commonly used
\end{abstract}

Correspondence to: A. S. H. Prévôt (andre.prevot@psi.ch) marker for primary emissions of wood burning. This contribution at $m / z 60$ can overcompensate for the degradation of levoglucosan leading to an overestimation of the contribution of wood burning or biomass burning to the total OM. The primary organic emissions from the three different burners showed a wide range in O:C atomic ratio $(0.19-0.60)$ for the starting and flaming conditions, which also increased during aging. Primary wood burning emissions have a rather low relative contribution at $m / z 43(f 43)$ to the total organic mass spectrum. The non-oxidized fragment $\mathrm{C}_{3} \mathrm{H}_{7}^{+}$has a considerable contribution at $m / z 43$ for the fresh OA with an increasing contribution of the oxygenated ion $\mathrm{C}_{2} \mathrm{H}_{3} \mathrm{O}^{+}$during aging. After five hours of aging, the $\mathrm{OA}$ has a rather low $\mathrm{C}_{2} \mathrm{H}_{3} \mathrm{O}^{+}$signal for a given $\mathrm{CO}_{2}^{+}$fraction, possibly indicating a higher ratio of acid to non-acid oxygenated compounds in wood burning OA compared to other oxygenated organic aerosol (OOA).

\section{Introduction}

Wood burning for domestic heating and cooking is very common in many parts of the world, and, because of its importance as a source of renewable energy, there is currently an increasing interest in its usage. By estimation, three billion people use small-scale appliances (three-stone fires or cooking stoves) that are both inefficient and highly polluting (World Energy Council, 2007). Wood combustion emits a wide range of volatile organic compounds (VOC) and particulate matter (PM) which consists mainly of organics and black carbon (BC) (McDonald et al., 2000; Schauer et al.,

Published by Copernicus Publications on behalf of the European Geosciences Union. 
2001). On a global scale, biomass burning is estimated to contribute up to $90 \%$ of the combustion generated primary particulate organic carbon (OC) (Bond et al., 2004). Wood burning is responsible for more than $30 \%$ of the particulate carbonaceous matter in Europe (Simpson et al., 2007) and was shown to be the dominant source of PM in Swiss Alpine valleys in winter (Sandradewi et al., 2008). These gas phase and PM emissions contribute to various adverse effects on human health (Nel, 2005; Pope and Dockery, 2006).

Organic aerosol $(\mathrm{OA})$ is an important fraction of the non-refractory $\mathrm{PM}_{1}$ ( $\mathrm{PM}$ with an aerodynamic diameter $d_{\mathrm{a}}<1 \mu \mathrm{m}$ ) in many parts of the world (Zhang et al., 2007). The OA mass spectra from the Aerodyne aerosol mass spectrometer (AMS) can be deconvolved to give information about sources contributing to the total OA mass (Lanz et al., 2007). Hydrocarbon-like OA (HOA) from traffic, biomass burning $\mathrm{OA}(\mathrm{BBOA})$, and oxygenated OA (OOA) were distinguished in many datasets where secondary organic aerosol (SOA) is assumed to be the main contributor to OOA (Lanz et al., 2010; Jimenez et al., 2009). OOA can be further separated into a low volatility fraction (LV-OOA), which is more aged and exhibits a higher $\mathrm{O}: \mathrm{C}$ ratio, and a semi-volatile fraction (SV-OOA) which represents fresher OOA with a lower O:C ratio (Lanz et al., 2007; Aiken et al., 2008; $\mathrm{Ng}$ et al., 2010; DeCarlo et al., 2010).

Levoglucosan was found to be a substantial constituent of primary organic aerosol (POA) particles from biomass burning (Fraser and Lakshmanan, 2000). The AMS mass spectrum of nebulized levoglucosan is highly correlated with ambient measurements at a wood burning dominated site in Roveredo, Switzerland. Three fragments, $m / z 60,73$, and 137, have been suggested as marker fragments for wood burning generated aerosols (Alfarra et al., 2007). The fragment at $\mathrm{m} / \mathrm{z} 60$ was observed for open burning (Lee et al., 2010) as well as for residential wood burners where the markers were found to depend on burning conditions and wood type (Weimer et al., 2008).

Aircraft measurements of aging wildfire plumes showed significantly increasing OA concentrations upon aging (Yokelson et al., 2009; DeCarlo et al., 2010). However, other aircraft studies report no increase in OM for aging wildfire plumes (Capes et al., 2008). Recent smog chamber studies investigating different types of open biomass burning emissions showed an average increase in OM by a factor of 1.7 (Hennigan et al., 2011). Emissions from a small wood burning appliance have been shown to form significant amounts of SOA during irradiation with UV light (Grieshop et al., 2009b). Such an aged OA closely resembles the OOA spectrum, which makes it difficult to extract the total contribution of wood burning in ambient OA. Smog chamber experiments are suitable to give insight into the properties of POA and to characterize the SOA from wood burning exhaust.

In this paper, we describe the POA, the SOA production, and OA aging processes from three different residential wood burning appliances during the startup and flaming phases using measurements from a high resolution time-offlight aerosol mass spectrometer (HR-TOF-AMS). SOA production and estimated emission factors for BC, POA, and SOA are reported for all three burners separated by starting phase and flaming phase. We present a correlation between $\mathrm{O}: \mathrm{C}$ ratio and $m / z 44$ obtained from unit mass resolution (UMR) mass spectra, which can be used to estimate the O:C ratio of wood burning aerosols, POA and SOA, from UMR data. In addition, results from pure SOA experiments, where only the gas phase emissions are injected into the chamber and processed, are presented.

\section{Materials and methods}

\subsection{Experimental setup}

The experiments were performed in the smog chamber of the Paul Scherrer Institute (PSI). The PSI chamber is a $27-\mathrm{m}^{3}$ Teflon bag suspended in a temperature controlled housing. The smog chamber was operated at $20^{\circ} \mathrm{C}$ and a relative humidity (RH) of $\sim 50 \%$ during all experiments described here. Four xenon arc lamps of $4 \mathrm{~kW}$ each were used to simulate the atmospheric light spectrum and intensity during a typical Swiss winter day at noon. The smog chamber housing is covered with a reflecting coating to increase light intensity and light diffusion. A more detailed description of the PSI smog chamber and its standard instrumentation can be found elsewhere (Paulsen et al., 2005).

The experiments were performed with two different residential log wood burners and one residential pellet burner. The first burner is an old style log wood burner (WESO Duplex, built around 1960) with a small $\left(\sim 0.018 \mathrm{~m}^{3}\right)$ combustion chamber. The second burner is a modern log wood burner (Attika Avant, 2009, combustion chamber $\sim 0.037 \mathrm{~m}^{3}$ ) with well defined air flows to reach optimal combustion efficiencies. The wood used for these burners, $100 \%$ beech, was obtained from a local distributor, cut into $\sim 400 \mathrm{~g}$ pieces and stored in a dry place. The logs were positioned on top of the kindling and lit from below. Emissions were injected into the smog chamber either during starting, flaming or smoldering phases of the burning cycle. For the starting phase experiments the kindling was lit using a small gas torch immediately before chamber injection. Experiments on the gas phase only emissions were performed by filtering the hot emissions through a heated filter $\left(150^{\circ} \mathrm{C}\right)$. These experiments are referred to as pure SOA experiments throughout the rest of this paper and are a combination of starting and flaming phase emissions. The pellet burner (Rüegg KEA, $2005, \mathrm{P}_{\max } 9 \mathrm{~kW}$ ) was operated at $80 \%$ of its maximum power using wood pellets. The burners were connected to a chimney with a diameter of $0.16 \mathrm{~m}$ and a height of $3.5 \mathrm{~m}$.

The introduction of the wood burning emissions into the chamber was done from a pickoff point in the middle of the chimney at a height of approximately $2 \mathrm{~m}$. To avoid particle 
Table 1. Overview of several parameters for the different smog chamber experiments.

\begin{tabular}{|c|c|c|c|c|c|c|c|}
\hline Experiment & POA & $\mathrm{OA}_{5 \mathrm{~h}} / \mathrm{POA}$ & POA & $\mathrm{OA}_{5 \mathrm{~h}}$ & $\mathrm{POA} / \mathrm{CO}$ & $\mathrm{MCE}^{\mathrm{a}}$ & $\Delta \mathrm{O}_{3} t_{5 \mathrm{~h}}-t_{0 \mathrm{~h}}$ \\
\hline & $\left(\mu \mathrm{g} / \mathrm{m}^{3}\right)$ & (WLC) & $\mathrm{O}: \mathrm{C}$ & $\mathrm{O}: \mathrm{C}$ & $\left(\mu \mathrm{g} / \mathrm{m}^{3} \mathrm{ppm}^{-1}\right)$ & & (ppb) \\
\hline \multicolumn{8}{|l|}{ Old log wood burner } \\
\hline 1 flaming + smoldering & 3.8 & 1.6 & 0.51 & 0.58 & 3.9 & 0.986 & 32 \\
\hline 2 flaming & 4.4 & 3.8 & 0.38 & 0.50 & $\mathrm{n} / \mathrm{a}$ & $\mathrm{n} / \mathrm{a}$ & 59 \\
\hline 3 flaming & 28 & 5.1 & 0.19 & 0.36 & 11 & 0.960 & 111 \\
\hline 4 starting & 27 & 6.9 & 0.32 & 0.42 & 7.6 & 0.943 & 52 \\
\hline 5 starting & 6.5 & 5.7 & 0.23 & 0.46 & 6.4 & 0.959 & 65 \\
\hline 6 smoldering & 17 & 0.7 & 0.87 & 0.79 & 14 & 0.909 & 16 \\
\hline 7 flaming & 7.6 & 3.8 & 0.25 & 0.36 & 38 & 0.994 & 10 \\
\hline \multicolumn{8}{|l|}{ Pellet burner } \\
\hline 8 stable burning & 4.2 & 1.0 & 0.23 & 0.50 & 48 & 0.999 & $\mathrm{n} / \mathrm{a}$ \\
\hline 9 starting & 3.6 & 2.8 & 0.52 & 0.72 & 29 & 0.992 & 26 \\
\hline 10 starting & 3.5 & 3.7 & 0.59 & 0.84 & 22 & 0.988 & 24 \\
\hline \multicolumn{8}{|l|}{ Modern log wood burner } \\
\hline 11 flaming & 1.4 & 3.6 & 0.48 & 0.62 & 2.5 & 0.993 & \\
\hline 12 flaming & 4.9 & 5.3 & 0.37 & 0.50 & 3.1 & 0.987 & 79 \\
\hline 13 flaming & 6.1 & 2.7 & 0.35 & 0.41 & 11 & 0.995 & 3 \\
\hline 14 gas-phase only ${ }^{b}$ & - & - & - & 0.50 & - & 0.989 & 73 \\
\hline 15 starting & 31 & 4.2 & 0.37 & 0.56 & 20 & 0.958 & 23 \\
\hline 16 starting & 3.9 & 3.4 & 0.41 & 0.62 & 28 & 0.979 & 12 \\
\hline 17 starting & 20 & 2.3 & 0.33 & 0.51 & 16 & 0.966 & 25 \\
\hline 18 gas-phase only ${ }^{\mathrm{b}}$ & - & - & - & 0.36 & - & 0.994 & 10 \\
\hline 19 gas-phase only ${ }^{b}$ & - & - & - & 0.39 & - & 0.993 & 25 \\
\hline 20 flaming & 2.0 & 2.1 & 0.50 & 0.54 & 5.8 & 0.995 & 2 \\
\hline
\end{tabular}

${ }^{a}$ Modified combustion efficiency defined as $\left[\mathrm{CO}_{2}\right] /\left(\left[\mathrm{CO}_{2}\right]+[\mathrm{CO}]\right)$.

$\mathrm{b}$ Gas-phase only experiments were performed on a mixture of starting and flaming phase emissions.

coagulation, the emissions were diluted by a factor of $\sim 7$ using a heated ejector diluter (Dekati Ltd., Tampere, Finland). The preheated dilution air was provided by a pure air generator (737-250 series, AADCO Instruments, Inc., USA). The dilution system, dilution air, and all sampling lines were usually operated at $150^{\circ} \mathrm{C}$ to prevent condensation of semi-volatile organic compounds (SVOC's). Finally, the emissions experienced a second dilution $(\sim 220$ times) and cooling to $20^{\circ} \mathrm{C}$ when entering the smog chamber. A schematic representation of the inlet system and the smog chamber setup is shown in Fig. 1. The filling time and/or the flow into the smog chamber were varied to achieve atmospherically relevant concentrations $\left(1-30 \mu \mathrm{g} / \mathrm{m}^{3}\right)$ of POA. The smoldering phase emissions generally produced low POA emissions and therefore only one smoldering experiment, which showed a high organic emission, is described in this paper.

After injection and a 15-min homogenization/mixing period the primary emissions were measured for 30-60 min before the xenon lamps were switched on to start photooxidation. After each experiment the smog chamber was cleaned by the addition of several ppm of ozone for $\sim 3 \mathrm{~h}$ and flushing the chamber with zero air for at least $36 \mathrm{~h}$. Blank experiments were performed to make sure that the organic matter $(\mathrm{OM})$ produced during the experiments is not significantly influenced by background impurities in the smog chamber. An overview of the experiments described in this paper can be found in Table 1. The table in the Supplement (Table S1) describes additional parameters for all experiments.

\subsection{Instrumentation}

\subsubsection{High resolution time of flight aerosol mass spectrometer}

An Aerodyne high resolution time-of-flight aerosol mass spectrometer (HR-TOF-AMS) was used for the on-line quantification of the submicron $\left(\mathrm{PM}_{1}\right)$ non-refractory aerosol components. The term "non-refractory" is assigned to those species that evaporate rapidly at $600^{\circ} \mathrm{C}$ under vacuum conditions, e.g. OM, $\mathrm{NH}_{4} \mathrm{NO}_{3}$ and $\left(\mathrm{NH}_{4}\right)_{2} \mathrm{SO}_{4}$ (Allan et al., 2004). Potassium salts like $\mathrm{KNO}_{3}$ or $\mathrm{K}_{2} \mathrm{SO}_{4}$ can not be quantitatively measured with the AMS. A detailed description can be found elsewhere (DeCarlo et al., 2006), however a short description is given here. 


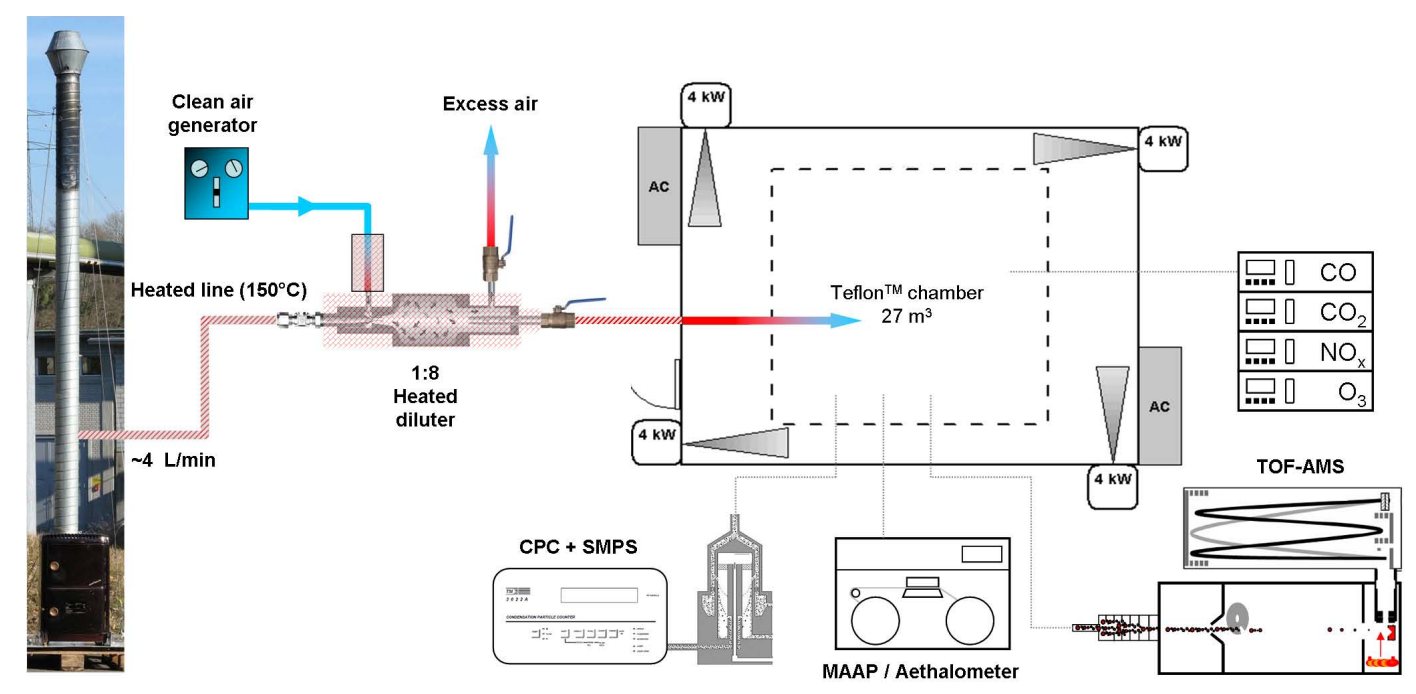

Fig. 1. Schematic representation of the inlet system and smog chamber setup.

The aerosol particles are sampled through a $100-\mu \mathrm{m}$ critical orifice into an aerodynamic lens which focuses particles into a narrow particle beam (Zhang et al., 2004). The inlet system shows $100 \%$ transmission for particles in the vacuum aerodynamic diameter range $70-500 \mathrm{~nm}$ and substantial transmission for particles in the range of $30-70 \mathrm{~nm}$ and $500 \mathrm{~nm}-1.5 \mu \mathrm{m}$. The largest mass concentration mode observed in the AMS pTOF mode was $\sim 400 \mathrm{~nm}$ which is well within the transmission window of the AMS. The expansion at the exit of the aerodynamic lens into the first vacuum chamber accelerates the particles towards a heated tungsten element. The particles are vaporized on impact and ionized by electron ionization (EI) at $70 \mathrm{eV}$. The produced ions are extracted from the ionization region into the TOF (H-TOF series, Tofwerk, Thun, Switzerland) followed by the orthogonal pulsed mass analysis.

The high mass resolution and accuracy of the HR-TOFAMS made it possible to determine the elemental composition of the ions up to approximately $\mathrm{m} / \mathrm{z} 100$ (DeCarlo et al., 2006). Integration of the organic ions with the elemental composition $\mathrm{C}_{\mathrm{x}} \mathrm{H}_{\mathrm{y}} \mathrm{O}_{\mathrm{z}} \mathrm{N}_{p}^{+}$gives information on the elemental ratios of O:C, H:C, N:C as well as the OM:OC ratio (Aiken et al., 2007; Aiken et al., 2008). Based on their elemental composition, ions were grouped into four different families: $\mathrm{C}_{\mathrm{x}} \mathrm{H}_{\mathrm{y}}(\mathrm{x} \geq 1$ and $\mathrm{y} \geq 0), \mathrm{C}_{\mathrm{x}} \mathrm{H}_{\mathrm{y}} \mathrm{O}_{\mathrm{z}}, \mathrm{C}_{\mathrm{x}} \mathrm{H}_{\mathrm{y}} \mathrm{N}_{p}$ and $\mathrm{C}_{\mathrm{x}} \mathrm{H}_{\mathrm{y}} \mathrm{O}_{\mathrm{z}} \mathrm{N}_{p}$ $(\mathrm{x} \geq 1, \mathrm{y} \geq 0, \mathrm{z} \geq 1$ and $p \geq 1)$. These families will be referred to as $\mathrm{CH}, \mathrm{CHO}, \mathrm{CHN}$ and $\mathrm{CHON}$ from hereon.

Data analysis was performed using Igor Pro 6 (Wavemetrics, Lake Oswego, OR) with the Squirrel TOF analysis toolkit v1.48 or later and the TOF HR analysis toolkit v1.07 or later. During every experiment, after filling and before lights on, HEPA filtered air was sampled from the smog chamber to measure the gas phase contributions to the mass spectra. The AMS fragmentation table (Allan et al., 2004) was modified accordingly for $m / z 16,18$, 29 and 44. In addition, the improved fragmentation table (Aiken et al., 2008) was used with the following fragmentation patterns in relation to the measured $\mathrm{CO}_{2}^{+}$signal: $\mathrm{CO}^{+}=100 \%, \mathrm{H}_{2} \mathrm{O}^{+}=22.5 \%, \mathrm{OH}^{+}=5.625 \%(25 \%$ of $\left.\mathrm{H}_{2} \mathrm{O}^{+}\right), \mathrm{O}^{+}=0.90 \%\left(4 \%\right.$ of $\left.\mathrm{H}_{2} \mathrm{O}^{+}\right)$. The contributions of these ions are added to the $\mathrm{CHO}$ family. A particle collection efficiency (CE) of 1 was used to estimate the nonrefractory aerosol mass concentration. This CE was based on the comparison of the sum of the AMS species and BC with a tapered element oscillating microbalance (TEOM, Series 1400a, Thermo Scientific) during a separate measurement campaign where primary emissions from a complete burning cycle of a log wood burner were sampled..

\subsubsection{Black carbon instrumentation}

BC was measured using an aethalometer (AE31, Magee Scientific Company, Berkeley CA) at $880 \mathrm{~nm}$ using a specific attenuation cross section of $16.6 \mathrm{~m}^{2} / \mathrm{g}$ and an empirical correction for the shadowing effect (Weingartner et al., 2003) during the first five experiments (Table 1). For the other experiments $\mathrm{BC}$ was measured with a multi angle absorption photometer (MAAP) (Model 5012, Thermo Fisher Scientific). BC concentrations were calculated at a one-minute time resolution using a mass specific absorption cross section of $6.6 \mathrm{~m}^{2} / \mathrm{g}$ at the wavelength $630 \mathrm{~nm}$.

\subsubsection{Gas phase instrumentation}

The evolution of several gas phase species was measured during the experiments. Carbon dioxide $\left(\mathrm{CO}_{2}\right)$ was measured using a differential, non-dispersive, infrared (NDIR) gas analyzer (LI-7000, Li-Cor Biosciences) operated with a time resolution of one second. Carbon monoxide (CO) was measured 
with an ultra fast fluorescence analyzer (AL5002, Aerolaser $\mathrm{GmbH}$ ). A chemiluminescence $\mathrm{NO}_{\mathrm{x}}$ analyzer (Monitor Labs model ML9841A) was used to measure $\mathrm{NO}$ and $\mathrm{NO}_{\mathrm{x}}$ $\left(\mathrm{NO}+\mathrm{NO}_{2}\right)$ and ozone $\left(\mathrm{O}_{3}\right)$ was measured with an ozone analyzer (Monitor Labs Inc. Model 8810).

\section{Results and discussion}

\subsection{Primary emissions}

The starting phase and flaming phase emissions from the old $\log$ wood burner were dominated by $\mathrm{BC}$ with an average $\mathrm{OM} / \mathrm{BC}$ ratio of $0.21 \pm 0.06$. The $\mathrm{OM} / \mathrm{BC}$ ratio for the modern log wood burner changed significantly between the starting phase and the flaming phase, with values of $1.2 \pm 0.4$ and $0.12 \pm 0.04$, respectively. The emissions from the pellet burner showed an average ratio of $2.5 \pm 0.9$ for the starting phase and during stable burning conditions. $\mathrm{OM} / \mathrm{BC}$ ratios were found to be lower than published values for offline methods (Szidat et al., 2006 and the references therein) and on the lower end of previously published smog chamber data (Grieshop et al., 2009b). Two possible explanations can be given. Our experiments were at lower concentrations (1$30 \mu \mathrm{g} / \mathrm{m}^{3}$ as compared to $\geq 40 \mu \mathrm{g} / \mathrm{m}^{3}$ ), which affects the partitioning of organics between the gas and particle phase (Lipsky and Robinson, 2006), and the modified combustion efficiency (MCE, defined as $\left.\left[\mathrm{CO}_{2}\right] /\left(\left[\mathrm{CO}_{2}\right]+[\mathrm{CO}]\right)\right)$ was higher (Table 1) which has been shown to lead to lower OM/BC ratios (Grieshop et al., 2009b).

\subsection{Secondary organic aerosol production}

Figure 2 shows the evolution of $\mathrm{OM}, \mathrm{NO}_{3}, \mathrm{SO}_{4}$ and $\mathrm{BC}$ for a typical experiment (No. 5 Table 1) with log wood burner emissions. After the injection, 15 min mixing time and the characterization of the primary emissions, the smog chamber lights were switched on. During the dark phase the concentrations of $\mathrm{BC}$ and $\mathrm{OM}$ decrease due to wall loss. The total PM mass as measured by the AMS was dominated by OM for all experiments. On average, the highest OM fractions were measured for the starting phase of the log wood burner (93\%), followed by the starting phase of the pellet burner $(86 \%)$, the flaming phase of the log wood burners $(76 \%)$ and the stable burning phase of the pellet burner (53\%). After the lights were switched on, the production rate of $\mathrm{OM}$ is greater than the wall loss rate, resulting in a rapid OM concentration increase from SOA formation in the first hour. In the second hour of lights on, the OM production rate slows down and OM reaches its maximum concentration once the SOA production rate equals the wall loss rate. After two hours, the wall loss rate dominates, resulting in a slow decrease in the measured OM concentration.

The wall loss rate was determined using $\mathrm{BC}$ as an inert tracer. Based on the assumption that the aerosol is internally

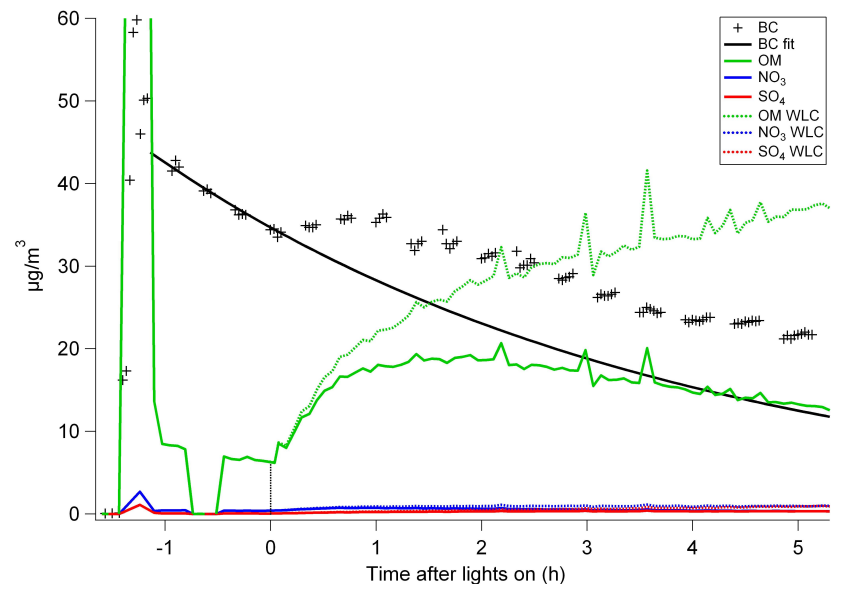

Fig. 2. Temporal evolution of the AMS species and BC (aethalometer) for the starting phase emissions of the modern log wood burner (experiment No. 5). BC data was fitted for the time period prior to lights on. Wall loss corrected (WLC) time series are calculated according to Eq. (2).

mixed and that particles deposited at the walls are in equilibrium with the suspended material, the wall loss rate of $\mathrm{BC}$ can be used to correct the concentrations of other particulate species (Grieshop et al., 2009b). The wall loss corrected concentration of $\mathrm{OM}\left(\mathrm{OM}_{\mathrm{WLC}}\right)$ can be derived using the equation:

$\mathrm{OM}_{\mathrm{WLC}}(t)=\mathrm{OM}_{\text {meas }}(t) \times\left[\frac{\mathrm{BC}\left(t_{0}\right)}{\mathrm{BC}(t)}\right]$

where $\mathrm{OM}_{\text {meas }}(t)$ refers to the concentration of OM measured at time $t . \mathrm{BC}\left(t_{0}\right)$ and $\mathrm{BC}(t)$ are the concentrations of $\mathrm{BC}$ when lights were switched on and at time $t$, respectively.

During some experiments, as shown in Fig. 2, an apparent increase in the $\mathrm{BC}$ concentration was seen after lights were switched on and OM increased substantially. This observation due to increased light absorption by BC with thicker coatings is in agreement with findings in the literature. An increase in light absorption efficiency due to an organic coating up to a factor of $\sim 2$ has previously been reported (Schnaiter et al., 2005; Shiraiwa et al., 2010). In similar experiments using diesel exhaust in the PSI smog chamber this increase of black carbon concentration was not observed, likely due to a thinner coating (Chirico et al., 2010). This increase in absorption leads to an underestimation of the wall loss rate and consequent underestimation of the SOA production if the $\mathrm{BC}$ concentration calculated from the absorption measurement is used. To get a representative wall loss rate the $\mathrm{BC}$ data was fit for the time period prior to lights on using an exponential fit to zero. Equation (1) can be modified to:

$\mathrm{OM}_{\mathrm{WLC}}(t)=\mathrm{OM}_{\text {meas }}(t) \times\left[\frac{\mathrm{BC}_{\mathrm{fit}}\left(t_{0}\right)}{\mathrm{BC}_{\mathrm{fit}}(t)}\right]$

where $\mathrm{BC}_{\mathrm{fit}}\left(t_{0}\right)$ and $\mathrm{BC}_{\mathrm{fit}}(t)$ are the concentrations of $\mathrm{BC}$ derived from the exponential fit when lights were switched on 


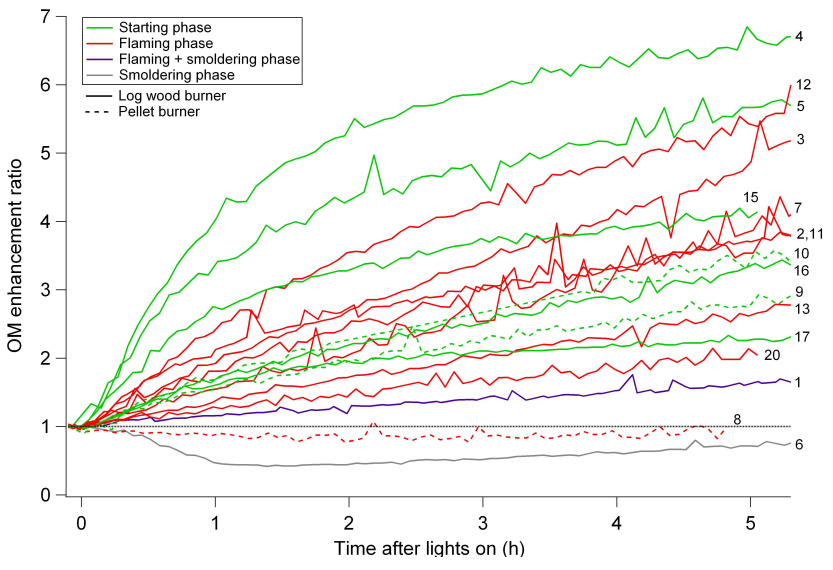

Fig. 3. Wall loss corrected OM enhancement ratios for the different burners and burning conditions.

and at time $t$ respectively. The pure SOA experiments were not used to quantify the SOA formation and therefore were not corrected for wall losses.

The relative increase of $\mathrm{OM}$ in relation to the concentration of POA is expressed as the OM enhancement ratio $\left(\mathrm{OM}_{\mathrm{ER}}\right)$. Taking the wall loss correction as shown in Eq. (2) into account, the $\mathrm{OM}_{\mathrm{ER}}$ at time $t$ can be calculated by:

$\mathrm{OM}_{\mathrm{ER}}(t)=\left[\frac{\mathrm{OM}_{\text {meas }}(t)}{\mathrm{OM}_{\text {meas }}\left(t_{0}\right)}\right] \times\left[\frac{\mathrm{BC}_{\text {fit }}\left(t_{0}\right)}{\mathrm{BC}_{\text {fit }}(t)}\right]$

The temporal evolutions of the OM enhancement ratios for all smog chamber experiments are shown in Fig. 3.

All log wood burner experiments show a substantial increase in $\mathrm{OM}$ for both starting and flaming phase emissions. The average $\mathrm{OM}_{\mathrm{ER}}$ for these experiments after $5 \mathrm{~h}$ of photooxidation was found to be 4.1 1 1.4. During injection for experiment No. 1, the fire stopped flaming and started smoldering which may be the reason for the lower $\mathrm{OM}_{\mathrm{ER}}$ of 1.6. In contrast, the high emission smoldering event (No. 6) showed an OM loss of $54 \%$ (after wall loss correction) within the first hour and a slow increase during the following hours. The mass loss during this experiment is discussed in detail in Sect. 3.5. The pellet burner produced an average $\mathrm{OM}_{\mathrm{ER}}$ of $3.3 \pm 0.6$ during the starting phase whereas no SOA formation was observed for the flaming phase, which is explained by the very stable and controlled burning conditions for the pellet burner in contrast to the log wood ovens.

\subsection{Emission factors}

To perform smog chamber experiments at atmospherically relevant OM concentrations it was necessary to adjust the filling time and dilution factor to the type of burner and burning condition to stay below $40 \mu \mathrm{g} / \mathrm{m}^{3}$ primary OM concentration. Therefore the concentrations of the measured aerosol species need scaling before they can be compared or averaged. Two abundant gas phase products from wood burning, $\mathrm{CO}_{2}$ and

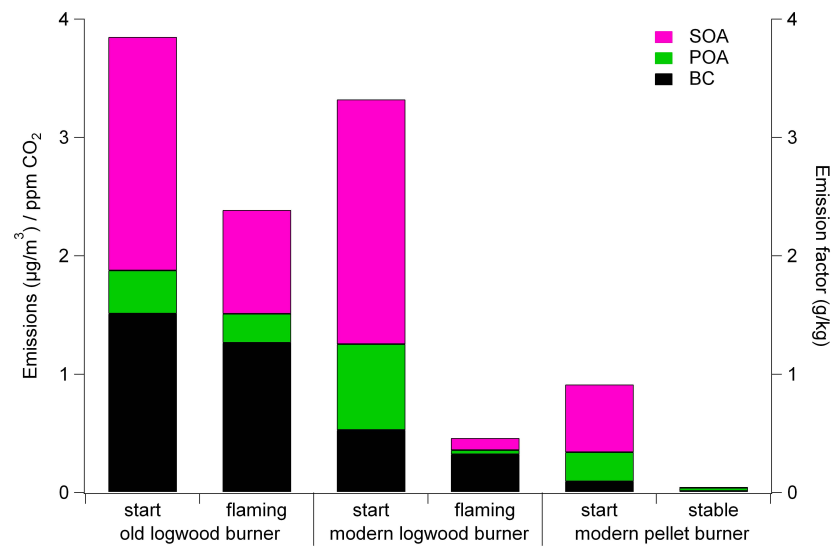

Fig. 4. Average concentrations of $\mathrm{BC}, \mathrm{POA}$ and $\mathrm{SOA}$ after $5 \mathrm{~h}$ of aging normalized by the increase in $\mathrm{CO}_{2}$ concentration. The right axis shows the estimated emission factor in $\mathrm{g} / \mathrm{kg}$ wood burnt.

$\mathrm{CO}$, were found to be useful scalars for dilution effects and emission factors. The average concentrations of $\mathrm{BC}, \mathrm{POA}$ and SOA, normalized by the increase in the $\mathrm{CO}_{2}$ concentration, for the different burners and burning conditions are shown in Fig. 4.

Since there was no information on the mass of wood burned during injection, an estimate of the emission factors were calculated based on the increase in $\mathrm{CO}_{2}$ concentration. The mass of wood burned was calculated using the following formula

$m_{\mathrm{WB}}=\frac{P \times V}{R \times T} \times \Delta \mathrm{CO}_{2} \times M_{\mathrm{W}} \mathrm{C} \times \frac{1}{f_{\mathrm{C}}}$

where $m_{\mathrm{WB}}$ is the mass of wood burned $(\mathrm{g}), \Delta \mathrm{CO}_{2}$ the increase in concentration (ppm), $\mathrm{M}_{\mathrm{W}} \mathrm{C}$ the molecular mass of carbon, and $f_{\mathrm{C}}$ the carbon fraction of wood. $P, V, R$ and $T$ are the pressure $(\mathrm{Pa})$, volume $\left(\mathrm{m}^{3}\right)$, universal gas constant, and temperature $(\mathrm{K})$ respectively. Using a carbon fraction of $50 \%$ for beech (Joosten et al., 2004), a 1-ppm increase in $\mathrm{CO}_{2}$ per cubic meter air in the smog chamber corresponds to $1 \mathrm{mg}$ burned wood. These estimated emissions factors, in $\mathrm{g} / \mathrm{kg}$ wood burnt, are shown on a second axis in Fig. 4.

All of the burners tested showed higher emission factors for $\mathrm{BC}$, POA and SOA during the startup phase compared to the flaming or stable phases. The old log wood burner produced the highest total emissions during the starting phase and flaming phase followed by the new log wood burner and then the pellet burner. All values from Fig. 4 as well as their standard deviations are presented in Table 2.

The old log wood burner showed a similar BC production during the starting and flaming phase. Total OM (POA + SOA) showed a slightly smaller emission factor during the flaming phase. The similarity between starting and flaming phases may be explained by the small combustion chamber, which leads to relatively inefficient combustion even under flaming conditions. The modern log wood burner 
Table 2. Emission factors of BC, POA and SOA normalized to the amount of wood burnt $(\mathrm{g} / \mathrm{kg})$ and their relative contribution to the total $\mathrm{PM}$ emissions $(\mathrm{OM}+\mathrm{BC})$ after $5 \mathrm{~h}$ of aging.

\begin{tabular}{lcccccc}
\hline Experiment $^{\mathrm{a}, \mathrm{b}}$ & $\mathrm{BC}(\mathrm{g} / \mathrm{kg})$ & $\mathrm{BC}(\%)$ & $\mathrm{POA}(\mathrm{g} / \mathrm{kg})$ & POA $(\%)$ & $\mathrm{SOA}(\mathrm{g} / \mathrm{kg})$ & $\mathrm{SOA}(\%)$ \\
\hline Old start & $1.51 \pm 0.11$ & 39 & $0.36 \pm 0.13$ & 10 & $2.0 \pm 1.0$ & 51 \\
Old flaming & $1.3 \pm 1.2$ & 53 & $0.25 \pm 0.19$ & 10 & $0.88 \pm 0.59$ & 37 \\
Modern start & $0.53 \pm 0.02$ & 16 & $0.73 \pm 0.19$ & 22 & $2.1 \pm 0.9$ & 62 \\
Modern flaming & $0.34 \pm 0.05$ & 71 & $0.03 \pm 0.01$ & 7 & $0.10 \pm 0.11$ & 22 \\
Pellet start & $0.10 \pm 0.03$ & 10 & $0.25 \pm 0.03$ & 27 & $0.57 \pm 0.23$ & 63 \\
Pellet stable & 0.014 & 33 & 0.027 & 67 & 0 & 0 \\
\hline
\end{tabular}

a Old = old log wood burner.

${ }^{\mathrm{b}}$ Modern $=$ modern log wood burner

showed similar BC emission factors during the starting phase and flaming phase, but was roughly a factor of 3-4 lower than the old wood stove. The emission factor of $\mathrm{OM}$ for the modern log wood burner was significantly lower during the flaming phase. This indicates that the new design with a large combustion chamber and sophisticated airflows decreases the emission factors for OM once the burner reaches operating temperatures. The improved design of the new log wood burner thus influences both the primary emissions and secondary formation of organic aerosol. The emission factors of the pellet burner were dominated by $\mathrm{OM}$ and were considerably lower during stable burning compared to the starting phase. A wide range of $\mathrm{POA} / \mathrm{CO}$ ratios (3.9$48 \mu \mathrm{g} / \mathrm{m}^{3} \mathrm{ppm}^{-1}$ ) were observed for the different burners and burning conditions (Table 1). This range is in agreement with the average $\mathrm{OM} / \mathrm{CO}$ ratio of 38 that was found for the wood burning dominated site in Roveredo, Switzerland (Gaeggeler et al., 2008) and with values found for other smog chamber studies (Grieshop et al., 2009a; Grieshop et al., 2009b).

\subsection{High resolution analysis of primary and aged organic aerosols}

The high resolution organic mass spectra were fitted with a fitting procedure resulting in a peak separation by fragment ions (DeCarlo et al., 2006). These ions were grouped into $\mathrm{CH}, \mathrm{CHO}, \mathrm{CHN}$ and $\mathrm{CHON}$ families. In general, the $\mathrm{CHN}$ and $\mathrm{CHON}$ families have only a small contribution $(<10 \%)$ to the total organic spectrum from the tested wood burners. The two dominant classes for all conditions were the $\mathrm{CH}$ and CHO families.

Emissions from wood burning are highly variable in quantity and properties as shown above. An example of the family spectra of the POA and of the aged organic aerosol is shown in Fig. 5. Experiment No. 15 was chosen as it is in the middle of the observed range in SOA production and $\mathrm{O}: \mathrm{C}$ ratio. POA is dominated by $\mathrm{CHO}(51.9 \%)$ followed by $\mathrm{CH}(43.6 \%), \mathrm{CHN}(3.2 \%)$ and $\mathrm{CHON}(1.3 \%)$. After $5 \mathrm{~h}$ of aging, $\mathrm{CHO}$ showed an increase to $63.3 \%$ whereas $\mathrm{CH}$ decreased to $31.1 \%$. CHN increased from $3.2 \%$ to $4.4 \%$ and

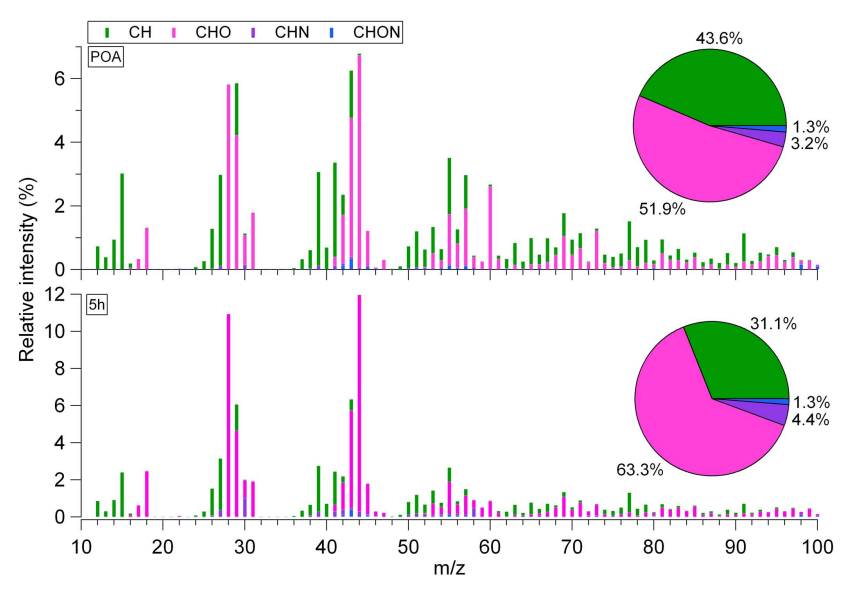

Fig. 5. Mass spectra of the starting phase log wood burner experiment (No. 15). The top panel shows the POA and the lower panel the organic aerosol after $5 \mathrm{~h}$ of aging. Ions are grouped into the families $\mathrm{CH}, \mathrm{CHO}, \mathrm{CHN}$ and $\mathrm{CHON}$ based on their elemental composition. The pie charts show the relative contributions of the families.

CHON stayed constant at $1.3 \%$. The POA spectrum shows a strong signal for the ion series at $m / z 27,41,55,69,83$ and $m / z 29,43,57,71$ which are often assigned to cycloalkanes or alkenes $\left(\mathrm{C}_{n} \mathrm{H}_{2 n-1}^{+}\right)$and normal or branched alkanes $\left(\mathrm{C}_{n} \mathrm{H}_{2 n+1}^{+}\right)$respectively (Alfarra et al., 2004; Canagaratna et al., 2004; Weimer et al., 2008). However, the high resolution data shows that, except for $m / z 27$ and 41, the signals are dominated by oxygen containing ions and cannot be assigned to either of these hydrocarbon series alone.

Levoglucosan, a product from wood burning and biomass burning, has been used as molecular marker in ambient organic aerosol (Fraser and Lakshmanan, 2000; Simoneit et al., 1999). The ion at $m / z 60$, a dominant fragment in the mass spectrum of levoglucosan, has been used as a wood burning marker for AMS measurements in order to estimate the wood burning contribution to the ambient organic aerosol (Alfarra et al., 2007; DeCarlo et al., 2008). An ideal molecular marker is specific and inert, however, recent studies showed that 


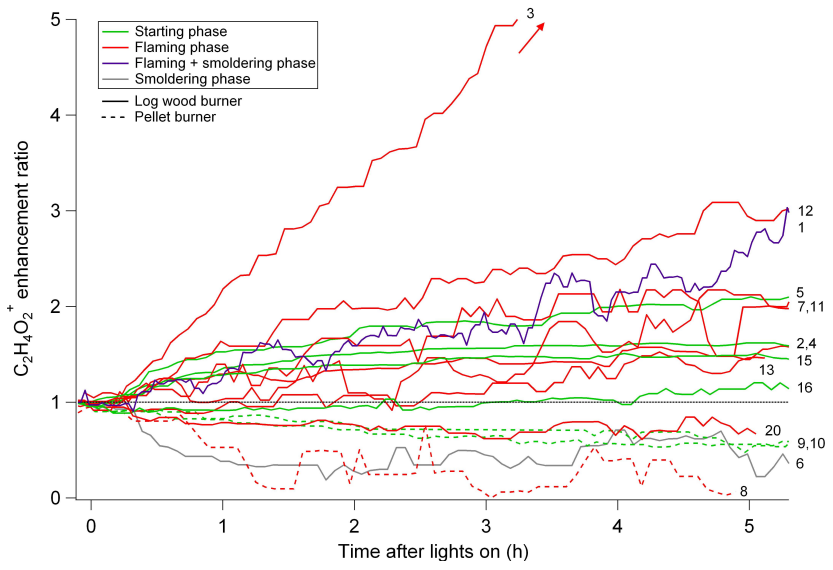

Fig. 6. Wall loss corrected enhancement ratios of the $\mathrm{C}_{2} \mathrm{H}_{4} \mathrm{O}_{2}^{+}$ion at $m / z 60.0211$ for the different burners and burning conditions.

levoglucosan is not stable under atmospheric conditions with an atmospheric lifetime of 0.7-2.2 days at an $\mathrm{OH}$ exposure of $1 \times 10^{6}$ molecules $\mathrm{cm}^{-3}$ (Hennigan et al., 2010; Hoffmann et al., 2010). This reactivity can lead to an underestimation of the wood burning contribution to ambient OM. Conversely, $\mathrm{m} / \mathrm{z} 60$ is not a unique fragment of levoglucosan and was found to contribute $\sim 0.3 \%$ to ambient OA during non-fire periods (Aiken et al., 2009; DeCarlo et al., 2008; Docherty et al., 2008). In addition, $m / z 60$ was also found in OOA spectra retrieved by PMF which are generally assumed to be dominated by SOA. Cubison et al. (2011) reported that only a minor fraction of the fragment at $m / z 60$ is from levoglucosan, mannosan or galactosan and hypothesized that $m / z 60$ may also result from similar molecules, and may include dimers and trimers.

AMS reference spectra of levoglucosan ( $\geq 98 \%$, Fluka) showed that the signal at $\mathrm{m} / \mathrm{z} 60$ corresponds to the ion $\mathrm{C}_{2} \mathrm{H}_{4} \mathrm{O}_{2}^{+}$fit at $m / z 60.0211$. The wall loss corrected evolution of this ion for all smog chamber experiments is shown in Fig. 6. A decrease in $\mathrm{C}_{2} \mathrm{H}_{4} \mathrm{O}_{2}^{+}$was observed for the pellet burner experiments and the smoldering experiments. One $\log$ wood burner experiment showed a decrease, whereas the remaining 11 experiments showed an increase in $\mathrm{C}_{2} \mathrm{H}_{4} \mathrm{O}_{2}^{+}$. This increase in the signal must result from SOA products that contribute to the same $\mathrm{C}_{2} \mathrm{H}_{4} \mathrm{O}_{2}^{+}$fragment as levoglucosan. These SOA products depend on the burning conditions and were not observed during the aging experiments performed with the pellet burner. The contribution of SOA to the $\mathrm{C}_{2} \mathrm{H}_{4} \mathrm{O}_{2}^{+}$ion at $\mathrm{m} / z 60$ can overcompensate for the degradation of levoglucosan, thus leading to an overestimation of the contribution of either wood burning or biomass burning to the total OM if this ion is used as a tracer for primary wood burning or biomass burning aerosol in ambient measurements. Concurrent measurements of levoglucosan and aerosol mass spectra were recently performed in our chamber and will be analyzed and published in the near future.

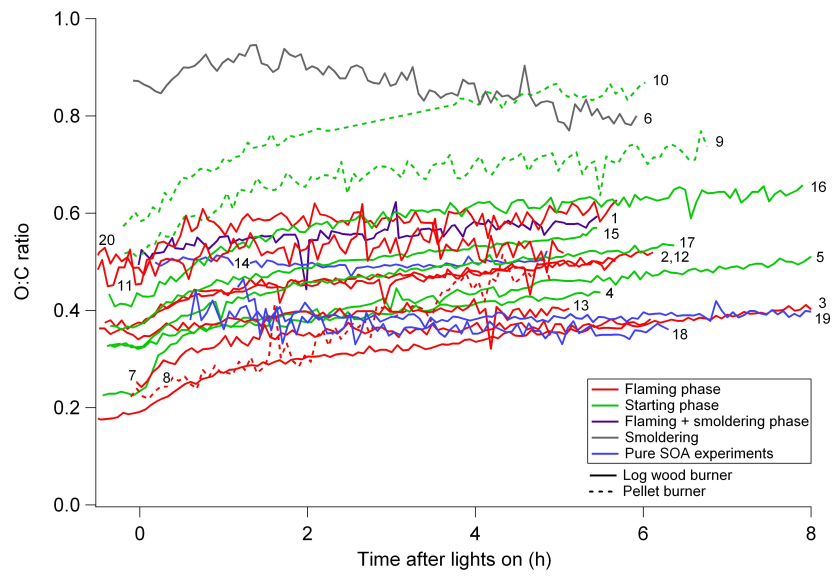

Fig. 7. Evolution of the O:C ratio for the different burners and burning conditions.

\subsection{Elemental ratios}

From the high resolution AMS spectra the average elemental composition and different atomic ratios can be derived (Aiken et al., 2007). The bulk organic aerosol properties can change by condensation of SOA and/or heterogeneous chemistry. During oxidation OA becomes more oxygenated, less volatile, and more hygroscopic such that the $\mathrm{O}: \mathrm{C}$ ratio can be used as an approximation for the degree of oxidation of the organic aerosol (Jimenez et al., 2009).

Figure 7 shows the evolution of the O:C ratio for all smog chamber experiments. The O:C ratios of the freshly emitted organic aerosol were highly variable and spanned the range of 0.19-0.58 for the different starting and flaming phase experiments. There was no separation in O:C ratio possible between the starting and flaming phases, nor between the different burners. The smoldering experiment (No. 6) showed a significantly higher $\mathrm{O}: \mathrm{C}$ ratio, of 0.87 , compared to the starting and flaming phases. All experiments on the primary emissions showed an increase in the $\mathrm{O}: \mathrm{C}$ ratio after lights on, with the exception of the smoldering phase experiment. Different rates for the increase in the $\mathrm{O}: \mathrm{C}$ ratio were found for the first two hours after lights on compared to the last period $(3-5 \mathrm{~h})$. For the $\log$ wood burners the $\mathrm{O}: \mathrm{C}$ ratio increased initially by $0.055 \pm 0.020$ and $0.036 \pm 0.012$ per hour for the starting phase and flaming phase respectively. This is $3-5$ times faster than for the latter part of the experiments where it increased by $0.016 \pm 0.004$ and $0.007 \pm 0.010$ per hour for the starting phase and flaming phase respectively. The O:C ratio of the start-up emissions from the pellet burner increased by $0.086 \pm 0.010$ during the first two hours and $0.007 \pm 0.010$ during the last two hours of the experiment. The pure SOA experiments did not show an increase during the first two hours $(-0.03 \pm 0.03)$ and no significant increase during the last two hours $(0.003 \pm 0.005)$, indicating that the $\mathrm{O}: \mathrm{C}$ ratio of the OM stayed constant during the first five hours of the 


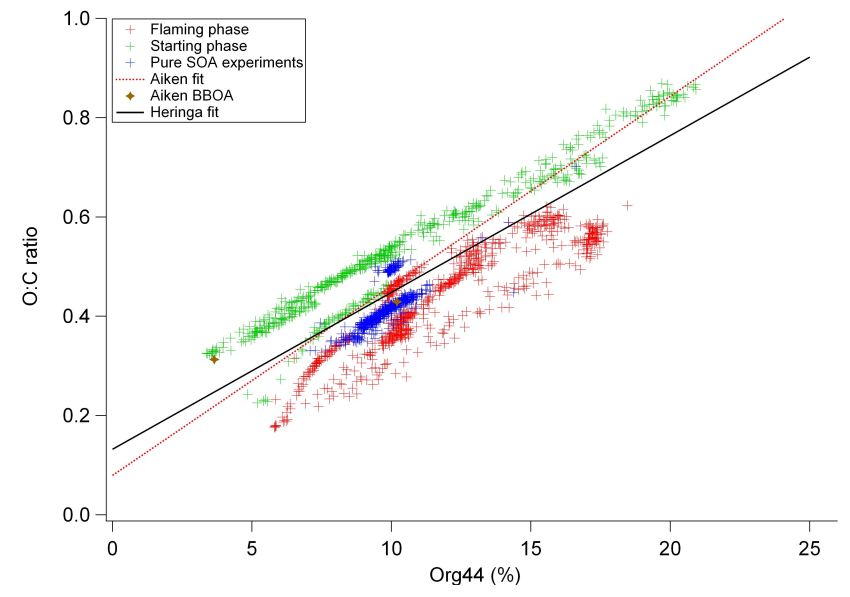

Fig. 8. Scatter plot of the O:C ratio vs. the percentage $m / z, 44$ of the normalized organic spectrum. The red line shows the correlation found for different ambient studies (Aiken et al., 2008). The black line shows the average of the fittings of the starting and flaming phase experiments $(0.0316 \pm 0.0005 \mathrm{x}+0.132 \pm 0.006)$.

experiment, which is the period where the OM concentration increase was most prominent. This increase in $\mathrm{OM}$ drives more volatile compounds with a lower $\mathrm{O}: \mathrm{C}$ ratio into the $\mathrm{OM}$ which could compensate the expected increase of the $\mathrm{O}: \mathrm{C}$ ratio by SOA addition. During a long pure SOA experiment, an increasing O:C ratio was observed after $6.5 \mathrm{~h}$ when the effect due to aging became more important than the one related to the addition of new mass. The fact that some experiments showed POA with a higher O:C ratio than the SOA produced during the pure SOA experiments could be the result of the influence of the burning conditions to the $\mathrm{O}: \mathrm{C}$ ratio of the VOC's similar to the OM.

During the smoldering experiment No. 6, an increase in the $\mathrm{O}: \mathrm{C}$ ratio was observed during the first $1.5 \mathrm{~h}$, which was then followed by a gradual decrease, while the OM had exactly the opposite trend. This peculiar behavior could potentially be explained by the fact that the POA seems to have a fraction of highly oxygenated OM and a smaller fraction of less oxygenated compounds. The loss of mass in the first hour of the experiment (Fig. 6) suggest that these less oxygenated species fragment upon oxidation and thus less likely partition into the OA (Jimenez et al., 2009). In the later phase semi-volatile species with a lower $\mathrm{O}: \mathrm{C}$ ratio than the existing $\mathrm{OM}$ condense on the aerosol resulting in a decrease in the $\mathrm{O}: \mathrm{C}$ ratio (Fig. 7).

The fraction of $m / z, 44$ at unit mass resolution can be used to estimate the $\mathrm{O}: \mathrm{C}$ ratio when their relationship is known. This relationship has been published for an analysis of ambient datasets (Aiken et al., 2008), but not for primary and secondary aerosols from domestic wood burning. Figure 8 shows the data for all starting and flaming phase experiments as well as from the pure SOA experiments. The slope of the separately fit starting and flaming phase experiments were
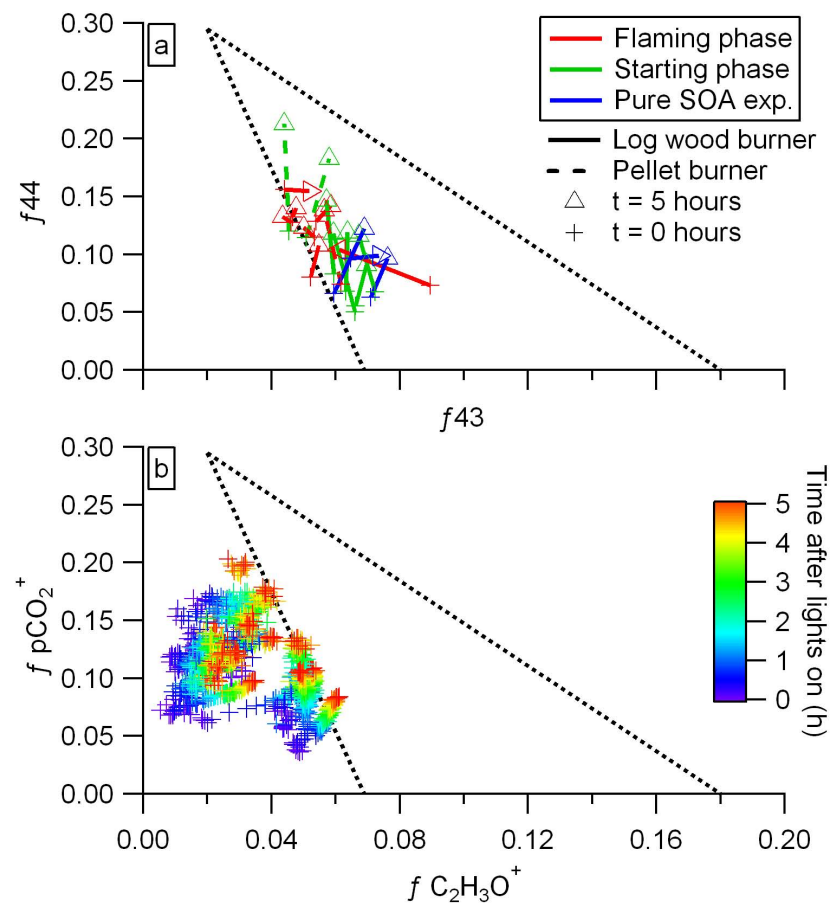

Fig. 9. Fraction plot of (a) mass $f_{44}$ vs. $f_{43}$ and (b) high resolution fit $f p \mathrm{CO}_{2}^{+}$vs. $f \mathrm{C}_{2} \mathrm{H}_{3} \mathrm{O}^{+}$. The triangular space found by $\mathrm{Ng}$ et al. (2010) to accommodate the OOA component of ambient organic aerosol is shown as well.

very similar with values of 0.033 and 0.030 respectively. The intercept found for the starting phase experiments is higher than the intercept for the flaming phase experiments and is therefore more sensitive to the number of experiments fit for each condition. The fitting shown in Fig. 8 is based on the average slope and intercept from the separate fittings of the starting and flaming phase experiments. It shows a slightly lower slope and higher intercept than reported for the ambient data.

Recently a new mass spectral diagnostic tool was developed to follow the aging of the OOA component in the atmosphere ( $\mathrm{Ng}$ et al., 2010). The fractions of two major masses, $m / z 44\left(\mathrm{CO}_{2}^{+}\right)$and $m / z 43$ (mostly $\mathrm{C}_{2} \mathrm{H}_{3} \mathrm{O}^{+}$) were used to create a triangular space $f 44$ vs. $f 43$ in which OOA moves towards the apex during the aging process. Thermal decomposition of acids at the heater of the AMS is known to be an important origin of the $\mathrm{CO}_{2}^{+}$fragment whereas $\mathrm{Ng}$ et al. (2010) hypothesized that the $\mathrm{C}_{2} \mathrm{H}_{3} \mathrm{O}^{+}$fragment is dominated by non-acid oxygenates. In Fig. 9a the POA at lights on $(\mathrm{t}=0 \mathrm{~h})$ and the bulk aerosol after five hours of aging is plotted in this two-dimensional space. Most data points are within this triangle close to the left margin whereby aging moves the data to higher $f 44$ for most experiments, whereas only a small increase or decrease was observed in the $f 43$. However, in contrast to OOA, the POA of wood burning has a significant contribution from the non-oxygenated ion 
$\mathrm{C}_{3} \mathrm{H}_{7}^{+}$at $m / z$ 43, increasing the $m / z$ 43/44 ratio. Using the $\mathrm{HR}$ data, it is possible to plot the fractions of the particle $\mathrm{CO}_{2}^{+}\left(p \mathrm{CO}_{2}^{+}\right)$and $\mathrm{C}_{2} \mathrm{H}_{3} \mathrm{O}^{+}$ions (Fig. 9b) which represent the OA functionalities better than the UMR data. The figure shows that the POA from all wood burning experiments have a characteristic low $\mathrm{C}_{2} \mathrm{H}_{3} \mathrm{O}^{+}$signal for a given $p \mathrm{CO}_{2}^{+}$ fraction compared to ambient OOA. During the SOA formation, the $p \mathrm{CO}_{2}^{+}$and $\mathrm{C}_{2} \mathrm{H}_{3} \mathrm{O}^{+}$fraction of the bulk aerosol increases, resulting in a shift in this space up and to the right. After $5 \mathrm{~h}$, about one third of the experiments were found at the lower edge of the $f \mathrm{C}_{2} \mathrm{H}_{3} \mathrm{O}^{+}$vs. $f p \mathrm{CO}_{2}^{+}$triangle found for ambient OOA, while the others were still outside the triangle.

\section{Conclusions}

In this study, we present the results from photo-oxidation smog chamber experiments on two different log wood burners and a residential pellet burner under different burning conditions. OM increased by SOA formation on average by a factor of $4.1 \pm 1.4$ for the starting and flaming phases of the two log wood burners. The startup phase of the pellet burner showed an increase by a factor of $3.3 \pm 0.6$, whereas no measureable SOA formation was observed for the stable burning phase. This implies that the gas phase emissions from log wood burners play an import role in the total contribution of OM from residential wood burning appliances to ambient $\mathrm{OM}$ and should be considered to be included in future legislations.

The primary organic emissions from the three different burners showed a wide range in the $\mathrm{O}: \mathrm{C}$ atomic ratio of OA (0.19-0.60) for all burning conditions and showed an increase during aging. The increase in the $\mathrm{O}: \mathrm{C}$ ratio was significantly faster during the first two hours compared to 3$5 \mathrm{~h}$ after lights on. After five hours of aging, the O:C ratio of the bulk aerosol reached values $>0.6$ for several experiments, which is close to the O:C ratio of LV-OOA found for aged ambient $\mathrm{OA}$.

The O:C ratio of the pure SOA experiments stayed relatively stable during the entire experiment. One smoldering event with high emissions was captured, which showed a decrease of the OM concentration accompanied by an increase in the $\mathrm{O}: \mathrm{C}$ ratio $(0.87$ to 0.95$)$ during the first $1.5 \mathrm{~h}$, followed by an increase of the OM concentration and a decrease in the O:C ratio. This exemplifies the complex combination of processes that are involved in aging (partitioning including condensation and evaporation, and oxidation coupled to either fragmentation or functionalization).

The wood burning marker at $m / z 60\left(\mathrm{C}_{2} \mathrm{H}_{4} \mathrm{O}_{2}^{+}\right.$fragment of levoglucosan) showed an increase in concentration for more than $90 \%$ of the log wood burner experiments for the starting and flaming phases. This increase is attributed to SOA species also contributing to this fragment. The formation of the precursor leading to this SOA contribution de- pends on the burning conditions, and is not observed during the pellet burner experiments. The contribution of SOA to the $\mathrm{C}_{2} \mathrm{H}_{4} \mathrm{O}_{2}^{+}$ion at $m / z 60$ can overcompensate the degradation of levoglucosan, thus leading to an overestimation of the contribution of either wood burning or biomass burning to the total $\mathrm{OM}$ if this ion is used as a tracer for primary wood burning or biomass burning aerosol in ambient measurements

The fractions of $\mathrm{C}_{2} \mathrm{H}_{3} \mathrm{O}^{+}$and $p \mathrm{CO}_{2}^{+}$, when projected onto the two-dimensional space described by $\mathrm{Ng}$ et al. (2010), was found to initially be outside of the triangle found for ambient OOA, but on aging moved up and to the right, towards the triangle. After five hours of aging, the OA has a rather low $\mathrm{C}_{2} \mathrm{H}_{3} \mathrm{O}^{+}$signal for a given $\mathrm{CO}_{2}^{+}$fraction, possibly indicating a higher ratio of acid to non-acid oxygenated compounds in wood burning OA compared to other OOA.

\section{Supplement related to this article is available online at: http://www.atmos-chem-phys.net/11/5945/2011/ acp-11-5945-2011-supplement.pdf.}

Acknowledgements. This work was supported by the IMBALANCE project of the Competence Center Environment and Sustainability of the ETH Domain (CCES), the Bundesamt für Umwelt (BAFU), the Bundesamt für Energie (BFE), as well as the Swiss National Science Foundation. PFD is grateful for the postdoctoral support from the US-NSF (IRFP\# 0701013). Attika Feuer AG is kindly acknowledged for the provided wood stove.

Edited by: J. B. Burkholder

\section{References}

Aiken, A. C., DeCarlo, P. F., and Jimenez, J. L.: Elemental analysis of organic species with electron ionization high-resolution mass spectrometry, Anal. Chem., 79, 8350-8358, 2007.

Aiken, A. C., DeCarlo, P. F., Kroll, J. H., Worsnop, D. R., Huffman, J. A., Docherty, K. S., Ulbrich, I. M., Mohr, C., Kimmel, J. R., Sueper, D., Sun, Y., Zhang, Q., Trimborn, A., Northway, M., Ziemann, P. J., Canagaratna, M. R., Onasch, T. B., Alfarra, M. R., Prevot, A. S. H., Dommen, J., Duplissy, J., Metzger, A., Baltensperger, U., and Jimenez, J. L.: O/C and OM/OC ratios of primary, secondary, and ambient organic aerosols with high-resolution time-of-flight aerosol mass spectrometry, Environ. Sci. Technol., 42, 4478-4485, 2008.

Aiken, A. C., Salcedo, D., Cubison, M. J., Huffman, J. A., DeCarlo, P. F., Ulbrich, I. M., Docherty, K. S., Sueper, D., Kimmel, J. R., Worsnop, D. R., Trimborn, A., Northway, M., Stone, E. A., Schauer, J. J., Volkamer, R. M., Fortner, E., de Foy, B., Wang, J., Laskin, A., Shutthanandan, V., Zheng, J., Zhang, R., Gaffney, J., Marley, N. A., Paredes-Miranda, G., Arnott, W. P., Molina, L. T., Sosa, G., and Jimenez, J. L.: Mexico City aerosol analysis during MILAGRO using high resolution aerosol mass spectrometry at the urban supersite (T0) - Part 1: Fine particle composition and organic source apportionment, Atmos. Chem. Phys., 9, 66336653, doi:10.5194/acp-9-6633-2009, 2009. 
Alfarra, M. R., Coe, H., Allan, J. D., Bower, K. N., Boudries, H., Canagaratna, M. R., Jimenez, J. L., Jayne, J. T., Garforth, A. A., Li, S. M., and Worsnop, D. R.: Characterization of urban and rural organic particulate in the lower Fraser valley using two aerodyne aerosol mass spectrometers, Atmos. Environ., 38, 5745$5758,2004$.

Alfarra, M. R., Prevot, A. S. H., Szidat, S., Sandradewi, J., Weimer, S., Lanz, V. A., Schreiber, D., Mohr, M., and Baltensperger, U.: Identification of the mass spectral signature of organic aerosols from wood burning emissions, Environ. Sci. Technol., 41, 57705777, 2007.

Allan, J. D., Delia, A. E., Coe, H., Bower, K. N., Alfarra, M. R., Jimenez, J. L., Middlebrook, A. M., Drewnick, F., Onasch, T. B., Canagaratna, M. R., Jayne, J. T., and Worsnop, D. R.: A generalised method for the extraction of chemically resolved mass spectra from Aerodyne aerosol mass spectrometer data, J. Aerosol Sci., 35, 909-922, 2004.

Bond, T. C., Streets, D. G., Yarber, K. F., Nelson, S. M., Woo, J. H., and Klimont, Z.: A technology-based global inventory of black and organic carbon emissions from combustion, J. Geophys. ResAtmos., 109, D14203, doi:10.1029/2003JD003697, 2004.

Canagaratna, M. R., Jayne, J. T., Ghertner, D. A., Herndon, S., Shi, Q., Jimenez, J. L., Silva, P. J., Williams, P., Lanni, T., Drewnick, F., Demerjian, K. L., Kolb, C. E., and Worsnop, D. R.: Chase studies of particulate emissions from in-use New York City vehicles, Aerosol. Sci. Technol., 38, 555-573, 2004.

Capes, G., Johnson, B., McFiggans, G., Williams, P. I., Haywood, J., and Coe, H.: Aging of biomass burning aerosols over West Africa: Aircraft measurements of chemical composition, microphysical properties, and emission ratios, J. Geophys. ResAtmos., 113, D00C15, doi:10.1029/2008JD009845, 2008.

DeCarlo, P. F., Ulbrich, I. M., Crounse, J., de Foy, B., Dunlea, E. J., Aiken, A. C., Knapp, D., Weinheimer, A. J., Campos, T., Wennberg, P. O., and Jimenez, J. L.: Investigation of the sources and processing of organic aerosol over the Central Mexican Plateau from aircraft measurements during MILAGRO, Atmos. Chem. Phys., 10, 5257-5280, doi:10.5194/acp-10-52572010, 2010.

Chirico, R., DeCarlo, P. F., Heringa, M. F., Tritscher, T., Richter, R., Prevot, A. S. H., Dommen, J., Weingartner, E., Wehrle, G., Gysel, M., Laborde, M., and Baltensperger, U.: Impact of aftertreatment devices on primary emissions and secondary organic aerosol formation potential from in-use diesel vehicles: results from smog chamber experiments, Atmos. Chem. Phys., 10, 11545-11563, doi:10.5194/acp-10-11545-2010, 2010.

Cubison, M. J., Ortega, A. M., Hayes, P. L., Farmer, D. K., Day, D., Lechner, M. J., Brune, W. H., Apel, E., Diskin, G. S., Fisher, J. A., Fuelberg, H. E., Hecobian, A., Knapp, D. J., Mikoviny, T., Riemer, D., Sachse, G. W., Sessions, W., Weber, R. J., Weinheimer, A. J., Wisthaler, A., and Jimenez, J. L.: Effects of aging on organic aerosol from open biomass burning smoke in aircraft and lab studies, Atmos. Chem. Phys. Discuss., 11, 12103-12140, doi:10.5194/acpd-11-12103-2011, 2011.

DeCarlo, P. F., Kimmel, J. R., Trimborn, A., Northway, M. J., Jayne, J. T., Aiken, A. C., Gonin, M., Fuhrer, K., Horvath, T., Docherty, K. S., Worsnop, D. R., and Jimenez, J. L.: Field-deployable, high-resolution, time-of-flight aerosol mass spectrometer, Anal. Chem., 78, 8281-8289, doi:10.1021/ac061249n, 2006.

DeCarlo, P. F., Dunlea, E. J., Kimmel, J. R., Aiken, A. C., Sueper,
D., Crounse, J., Wennberg, P. O., Emmons, L., Shinozuka, Y., Clarke, A., Zhou, J., Tomlinson, J., Collins, D. R., Knapp, D., Weinheimer, A. J., Montzka, D. D., Campos, T., and Jimenez, J. L.: Fast airborne aerosol size and chemistry measurements above Mexico City and Central Mexico during the MILAGRO campaign, Atmos. Chem. Phys., 8, 4027-4048, doi:10.5194/acp8-4027-2008, 2008.

Docherty, K. S., Stone, E. A., Ulbrich, I. M., DeCarlo, P. F., Snyder, D. C., Schauer, J. J., Peltier, R. E., Weber, R. J., Murphy, S. M., Seinfeld, J. H., Grover, B. D., Eatough, D. J., and Jimenez, J. L.: Apportionment of primary and secondary organic aerosols in Southern California during the 2005 study of organic aerosols in Riverside (SOAR-1), Environ. Sci. Technol., 42, 7655-7662, 2008.

Fraser, M. P., and Lakshmanan, K.: Using levoglucosan as a molecular marker for the long-range transport of biomass combustion aerosols, Environ. Sci. Technol., 34, 4560-4564, 2000.

Gaeggeler, K., Prevot, A. S. H., Dommen, J., Legreid, G., Reimann, S., and Baltensperger, U.: Residential wood burning in an Alpine valley as a source for oxygenated volatile organic compounds, hydrocarbons and organic acids, Atmos. Environ., 42, 82788287, 2008.

Grieshop, A. P., Donahue, N. M., and Robinson, A. L.: Laboratory investigation of photochemical oxidation of organic aerosol from wood fires 2: analysis of aerosol mass spectrometer data, Atmos. Chem. Phys., 9, 2227-2240, doi:10.5194/acp-9-2227-2009, 2009a.

Grieshop, A. P., Logue, J. M., Donahue, N. M., and Robinson, A. L.: Laboratory investigation of photochemical oxidation of organic aerosol from wood fires 1: measurement and simulation of organic aerosol evolution, Atmos. Chem. Phys., 9, 1263-1277, doi:10.5194/acp-9-1263-2009, 2009b.

Hennigan, C. J., Sullivan, A. P., Collett, J. L., and Robinson, A. L.: Levoglucosan stability in biomass burning particles exposed to hydroxyl radicals, Geophys. Res. Lett., 37, L09806, doi:10.1029/2010GL043088, 2010.

Hennigan, C. J., Miracolo, M. A., Engelhart, G. J., May, A. A., Presto, A. A., Lee, T., Sullivan, A. P., McMeeking, G. R., Coe, H., Wold, C. E., Hao, W. M., Gilman, J. B., Kuster, W. C., de Gouw, J., Schichtel, B. A., Collett Jr, J. L., Kreidenweis, S. M., and Robinson, A. L.: Chemical and physical transformations of organic aerosol from the photo-oxidation of open biomass burning emissions in an environmental chamber, Atmos. Chem. Phys. Discuss., 11, 11995-12037, doi:10.5194/acpd-11-11995-2011, 2011.

Hoffmann, D., Tilgner, A., Iinuma, Y., and Herrmann, H.: Atmospheric stability of levoglucosan: A detailed laboratory and modeling study, Environ. Sci. Technol., 44, 694-699, 2010.

Jimenez, J. L., Canagaratna, M. R., Donahue, N. M., Prevot, A. S. H., Zhang, Q., Kroll, J. H., DeCarlo, P. F., Allan, J. D., Coe, H., Ng, N. L., Aiken, A. C., Docherty, K. S., Ulbrich, I. M., Grieshop, A. P., Robinson, A. L., Duplissy, J., Smith, J. D., Wilson, K. R., Lanz, V. A., Hueglin, C., Sun, Y. L., Tian, J., Laaksonen, A., Raatikainen, T., Rautiainen, J., Vaattovaara, P., Ehn, M., Kulmala, M., Tomlinson, J. M., Collins, D. R., Cubison, M. J., Dunlea, E. J., Huffman, J. A., Onasch, T. B., Alfarra, M. R., Williams, P. I., Bower, K., Kondo, Y., Schneider, J., Drewnick, F., Borrmann, S., Weimer, S., Demerjian, K., Salcedo, D., Cottrell, L., Griffin, R., Takami, A., Miyoshi, T., Hatakeyama, S., 
Shimono, A., Sun, J. Y., Zhang, Y. M., Dzepina, K., Kimmel, J. R., Sueper, D., Jayne, J. T., Herndon, S. C., Trimborn, A. M., Williams, L. R., Wood, E. C., Middlebrook, A. M., Kolb, C. E., Baltensperger, U., and Worsnop, D. R.: Evolution of organic aerosols in the atmosphere, Science, 326, 1525-1529, 2009.

Joosten, R., Schumacher, J., Wirth, C., and Schulte, A.: Evaluating tree carbon predictions for beech (Fagus sylvatica L.) in Western Germany, Forest Ecol. Manag., 189, 87-96, 2004.

Lanz, V. A., Alfarra, M. R., Baltensperger, U., Buchmann, B., Hueglin, C., and Prevot, A. S. H.: Source apportionment of submicron organic aerosols at an urban site by factor analytical modelling of aerosol mass spectra, Atmos. Chem. Phys., 7, 15031522, doi:10.5194/acp-7-1503-2007, 2007.

Lanz, V. A., Prevot, A. S. H., Alfarra, M. R., Weimer, S., Mohr, C., DeCarlo, P. F., Gianini, M. F. D., Hueglin, C., Schneider, J., Favez, O., D'Anna, B., George, C., and Baltensperger, U.: Characterization of aerosol chemical composition with aerosol mass spectrometry in Central Europe: an overview, Atmos. Chem. Phys., 10, 10453-10471, 2010,

http://www.atmos-chem-phys.net/10/10453/2010/.

Lee, T., Sullivan, A. P., Mack, L., Jimenez, J. L., Kreidenweis, S. M., Onasch, T. B., Worsnop, D. R., Malm, W., Wold, C. E., Hao, W. M., and Collett, J. L.: Chemical smoke marker emissions during flaming and smoldering phases of laboratory open burning of wildland fuels, Aerosol. Sci. Technol., 44, I-V, 2010.

Lipsky, E. M. and Robinson, A. L.: Effects of dilution on fine particle mass and partitioning of semivolatile organics in diesel exhaust and wood smoke, Environ. Sci. Technol., 40, 155-162, 2006.

McDonald, J. D., Zielinska, B., Fujita, E. M., Sagebiel, J. C., Chow, J. C., and Watson, J. G.: Fine particle and gaseous emission rates from residential wood combustion, Environ. Sci. Technol., 34, 2080-2091, 2000.

Nel, A.: Air pollution-related illness: Effects of particles, Science, 308, 804-806, 2005.

Ng, N. L., Canagaratna, M. R., Zhang, Q., Jimenez, J. L., Tian, J., Ulbrich, I. M., Kroll, J. H., Docherty, K. S., Chhabra, P. S., Bahreini, R., Murphy, S. M., Seinfeld, J. H., Hildebrandt, L., Donahue, N. M., DeCarlo, P. F., Lanz, V. A., Prevot, A. S. H., Dinar, E., Rudich, Y., and Worsnop, D. R.: Organic aerosol components observed in Northern Hemispheric datasets from aerosol mass spectrometry, Atmos. Chem. Phys., 10, 4625-4641, doi:10.5194/acp-10-4625-2010, 2010.

Paulsen, D., Dommen, J., Kalberer, M., Prevot, A. S. H., Richter, R., Sax, M., Steinbacher, M., Weingartner, E., and Baltensperger, U.: Secondary organic aerosol formation by irradiation of 1,3,5trimethylbenzene- $\mathrm{NO}_{\mathrm{x}}-\mathrm{H}_{2} \mathrm{O}$ in a new reaction chamber for atmospheric chemistry and physics, Environ. Sci. Technol., 39, 2668-2678, 2005.

Pope, C. A. and Dockery, D. W.: Health effects of fine particulate air pollution: Lines that connect, J. Air Waste Manage., 56, 709_ $742,2006$.

Sandradewi, J., Prevot, A. S. H., Szidat, S., Perron, N., Alfarra, M. R., Lanz, V. A., Weingartner, E., and Baltensperger, U.: Using aerosol light absorption measurements for the quantitative determination of wood burning and traffic emission contributions to particulate matter, Environ. Sci. Technol., 42, 3316-3323, 2008.

Schauer, J. J., Kleeman, M. J., Cass, G. R., and Simoneit, B. R. T.: Measurement of emissions from air pollution sources. 3. $C_{1}-C_{29}$ organic compounds from fireplace combustion of wood, Environ. Sci. Technol., 35, 1716-1728, 2001.

Schnaiter, M., Linke, C., Mohler, O., Naumann, K. H., Saathoff, H., Wagner, R., Schurath, U., and Wehner, B.: Absorption amplification of black carbon internally mixed with secondary organic aerosol, J. Geophys. Res-Atmos., 110, D19204, doi:10.1029/2005JD006046, 2005.

Shiraiwa, M., Kondo, Y., Iwamoto, T., and Kita, K.: Amplification of light absorption of black carbon by organic coating, Aerosol. Sci. Technol., 44, 46-54, 2010.

Simoneit, B. R. T., Schauer, J. J., Nolte, C. G., Oros, D. R., Elias, V. O., Fraser, M. P., Rogge, W. F., and Cass, G. R.: Levoglucosan, a tracer for cellulose in biomass burning and atmospheric particles, Atmos. Environ., 33, 173-182, 1999.

Simpson, D., Yttri, K. E., Klimont, Z., Kupiainen, K., Caseiro, A., Gelencser, A., Pio, C., Puxbaum, H., and Legrand, M.: Modeling carbonaceous aerosol over Europe: Analysis of the CARBOSOL and EMEP EC/OC campaigns, J. Geophys. Res-Atmos., 112, D23S14, doi:10.1029/2006JD008158, 2007.

Szidat, S., Jenk, T. M., Synal, H.-A., Kalberer, M., Wacker, L., Hajdas, I., Kasper-Giebl, A., and Baltensperger, U.: Contributions of fossil fuel, biomass-burning, and biogenic emissions to carbonaceous aerosols in Zurich as traced by ${ }^{14} \mathrm{C}$, J. Geophys. Res., 111, D07206, doi:10.1029/2005JD006590, 2006.

Weimer, S., Alfarra, M. R., Schreiber, D., Mohr, M., Prévôt, A. S. H., and Baltensperger, U.: Organic aerosol mass spectral signatures from wood-burning emissions: Influence of burning conditions and wood type, J. Geophys. Res., 113, D10304, doi:10.1029/2007JD009309, 2008.

Weingartner, E., Saathoff, H., Schnaiter, M., Streit, N., Bitnar, B., and Baltensperger, U.: Absorption of light by soot particles: determination of the absorption coefficient by means of aethalometers, J. Aerosol Sci., 34, 1445-1463, 2003.

World Energy Council: 2007 Survey of energy resources, http://www.worldenergy.org/publications/ survey_of_energy_resources_2007/, last access: 18 June 2011, 2007.

Yokelson, R. J., Crounse, J. D., DeCarlo, P. F., Karl, T., Urbanski, S., Atlas, E., Campos, T., Shinozuka, Y., Kapustin, V., Clarke, A. D., Weinheimer, A., Knapp, D. J., Montzka, D. D., Holloway, J., Weibring, P., Flocke, F., Zheng, W., Toohey, D., Wennberg, P. O., Wiedinmyer, C., Mauldin, L., Fried, A., Richter, D., Walega, J., Jimenez, J. L., Adachi, K., Buseck, P. R., Hall, S. R., and Shetter, R.: Emissions from biomass burning in the Yucatan, Atmos. Chem. Phys., 9, 5785-5812, doi:10.5194/acp-9-5785-2009, 2009.

Zhang, Q., Jimenez, J. L., Canagaratna, M. R., Allan, J. D., Coe, H., Ulbrich, I., Alfarra, M. R., Takami, A., Middlebrook, A. M., Sun, Y. L., Dzepina, K., Dunlea, E., Docherty, K., DeCarlo, P. F., Salcedo, D., Onasch, T., Jayne, J. T., Miyoshi, T., Shimono, A., Hatakeyama, S., Takegawa, N., Kondo, Y., Schneider, J., Drewnick, F., Borrmann, S., Weimer, S., Demerjian, K., Williams, P., Bower, K., Bahreini, R., Cottrell, L., Griffin, R. J., Rautiainen, J., Sun, J. Y., Zhang, Y. M., and Worsnop, D. R.: Ubiquity and dominance of oxygenated species in organic aerosols in anthropogenically-influenced Northern Hemisphere midlatitudes, Geophys. Res. Lett., 34, L13801, doi:10.1029/2007GL029979, 2007.

Zhang, X. F., Smith, K. A., Worsnop, D. R., Jimenez, J. L., Jayne, 
J. T., Kolb, C. E., Morris, J., and Davidovits, P.: Numerical characterization of particle beam collimation: Part II - Integrated aerodynamic-lens-nozzle system, Aerosol. Sci. Technol., 38, 619-638, 2004. 